\title{
Both estrogen and raloxifene cause G1 arrest of vascular smooth muscle cells
}

\author{
K Takahashi $^{1,2}$, M Ohmichi ${ }^{1,2}$, M Yoshida $^{1}$, K Hisamoto $^{2}$, \\ S Mabuchi ${ }^{2}$, E Arimoto-Ishida ${ }^{2}$, A Mori ${ }^{1}$, S Tsutsumi ${ }^{1}$, K Tasaka $^{2}$, \\ Y Murata ${ }^{2}$ and $\mathbf{H}$ Kurachi $^{1}$ \\ ${ }^{1}$ Department of Obstetrics and Gynecology, Yamagata University School of Medicine, 2-2-2 lidanishi, Yamagata, Yamagata 990-9585, Japan \\ ${ }^{2}$ Department of Obstetrics and Gynecology, Osaka University Medical School, 2-2 Yamadaoka, Suita, Osaka 565-0871, Japan \\ (Requests for offprints should be addressed to M Ohmichi, Department of Obstetrics and Gynecology, Yamagata University School of Medicine, \\ 2-2-2 lidanishi, Yamagata, Yamagata 990-9585, Japan; Email: masa@med.id.yamagata-u.ac.jp)
}

\begin{abstract}
The proliferation of vascular smooth muscle cells (VSMC) is a crucial pathophysiological process in the development of atherosclerosis. Although estrogen is known to inhibit the proliferation of VSMC, the mechanism responsible for this effect remains to be elucidated. In addition, the effect of raloxifene on VSMC remains unknown. We have shown here that $17 \beta$-estradiol $\left(\mathrm{E}_{2}\right)$ and raloxifene significantly inhibited the platelet-derived growth factor (PDGF)-stimulated proliferation of cultured human VSMC. Flow cytometry demonstrated that PDGFstimulated S-phase progression of the cell cycle in VSMC was also suppressed by $E_{2}$ or raloxifene. We found that PDGF-induced phosphorylation of retinoblastoma protein $(\mathrm{pRb})$, whose hyperphosphorylation is a hallmark of the G1-S transition in the cell cycle, was significantly inhibited by $\mathrm{E}_{2}$ and raloxifene. These effects were associated with a decrease in cyclin D1 expression, without a change in cyclin-dependent kinase 4 or cyclin-dependent
\end{abstract}

kinase inhibitor, $\mathrm{p} 27^{\mathrm{kip} 1}$ expression. ICI 182,780 abolished the inhibitory effects of $\mathrm{E}_{2}$ and raloxifene on PDGFinduced $\mathrm{pRb}$ phosphorylation. Next, we examined which estrogen receptor (ER) is necessary for these effects of $E_{2}$ and raloxifene. Since VSMC express both ER $\alpha$ and ER $\beta$, A10, a rat aortic smooth muscle cell line that expresses ER $\beta$ but not ER $\alpha$, was used. The dose-dependent stimulation of A10 cell proliferation by PDGF was not inhibited by $\mathrm{E}_{2}$ or raloxifene in contrast to the results obtained in VSMC. Moreover, $\mathrm{E}_{2}$ and raloxifene significantly inhibited the PDGF-induced cyclin D1 promoter activity in A10 cells transfected with cDNA for ER $\alpha$ but not in the parental cells. These results suggested that $E_{2}$ and raloxifene exert an antiproliferative effect in VSMC treated with PDGF, at least in part through inhibition of $\mathrm{pRb}$ phosphorylation, and that the inhibitory effects of $E_{2}$ and raloxifene may be mainly mediated by $\operatorname{ER} \alpha$.

Journal of Endocrinology (2003) 178, 319-329

\section{Introduction}

The proliferation of vascular smooth muscle cells (VSMC) is a crucial pathophysiological process in the development of atherosclerosis and of restenosis after coronary angioplasty (Ross 1995, Schwarts et al. 1995, Hanke 1996, Braun-Dullaeus et al. 1998). VSMC are normally quiescent and display contractile properties. This contractility contributes to vasoconstriction and vasodilatation in the regulation of blood pressure and flow volume. Mechanical and/or chemical stresses alter the VSMC phenotype from the contractile to the synthetic state, and synthetic VSMC then migrate into the intima (Ross 1995).

Many epidemiological and basic studies demonstrated that estrogen affords cardioprotection in postmenopausal women (Stampfer et al. 1991, Mendelsohn \& Karas 1999). Although the results of the Women's Health Initiative's
(WHI) large prospective randomized controlled study seem to raise questions about the cardioprotective effect of estrogen (Writing Group for the Women's Health Initiative Investigators 2002), interim reports on women on estrogens alone did not show adverse effects on cardiovascular disease or breast cancer, and this part of the trial continues. Thus, the cardioprotective effect of estrogen itself was not necessarily disproven by the results of the WHI study. Moreover, there is a need for an ideal estrogen that does not increase the risk of breast cancer (Cummings et al. 1999). Raloxifene is a non-steroidal benzothiophene that has been classified as a selective estrogen receptor modulator based on the fact that it produces both estrogenagonistic effects on bone and lipid metabolism and estrogen-antagonistic effects on uterine endometrium and breast tissue. Although we found that raloxifene rapidly induces nitric oxide synthase activation in vascular 
endothelial cells (Hisamoto et al. 2001a), its ability to protect against cardiovascular disease has yet to be demonstrated and is now being tested in the Raloxifene Use for the Heart trial.

Several researchers have recently focused on the direct effects of estrogen on the endothelium and VSMC (Sullivan et al. 1995, Hisamoto et al. 2001b). We previously reported that estrogen rapidly induces nitric oxide synthase activation in vascular endothelial cells (Hisamoto et al. 2001b). Nitric oxide is secreted from normal endothelium and has important roles in maintaining normal vasculature, such as relaxation of vascular smooth muscle and inhibition of platelet activation (Moncada \& Higgs 1993). Platelet-derived growth factor (PDGF) is released from platelets, macrophages and endothelial cells, and is important in triggering VSMC proliferation and migration (Ross 1986, Schwartz et al. 1995). Some investigators have reported that estrogen inhibits PDGF-induced proliferation and migration of VSMC in vitro (Dai-Do et al. 1996, Kolodgie et al. 1996, Suzuki et al. 1996, Somjen et al. 1998). However, the mechanism responsible for this effect is not yet fully understood.

Recently, VSMC proliferation has been reported to be inhibited by a reduction of retinoblastoma protein $(\mathrm{pRb})$ phosphorylation and by modulation of cell cycle regulators (Kintscher et al. 2000, Marra et al. 2000, Wakino et al. 2001). The status of $\mathrm{pRb}$ phosphorylation is critical for cell proliferation. In quiescent cells, $\mathrm{pRb}$ is present in a hypophosphorylated state in which it is able to bind to and sequester members of the E2F family of transcription factors (Weinberg 1995). Phosphorylation of $\mathrm{pRb}$ at multiple sites induces a conformational change that releases $\mathrm{E} 2 \mathrm{~F}$, which in turn activates the transcription of genes required for further cell cycle progression (Nevins 1992, La Thangue 1996). Therefore, we hypothesized that the antiproliferative effect of estrogen in VSMC might be due to inhibition of $\mathrm{pRb}$ phosphorylation.

We report here that $17 \beta$-estradiol $\left(\mathrm{E}_{2}\right)$ exerts an antiproliferative effect through inhibition of $\mathrm{pRb}$ phosphorylation in PDGF-induced VSMC, and that the inhibitory effect of estrogen is mainly mediated by estrogen receptor $\alpha(\operatorname{ER} \alpha)$.

\section{Materials and Methods}

\section{Materials}

Raloxifene analogue LY117018 was a kind gift from Eli Lilly Research Laboratories (Indianapolis, IN, USA). $\mathrm{E}_{2}$ and propidium iodide were purchased from Sigma Chemical Co. (St Louis, MO, USA). ICI 182,780 was obtained from Tocris (Ballwin, MO, USA). PDGF was obtained from R\&D Systems, Inc. (Minneapolis, MN, USA). ECL Western blotting detection reagents were from Amersham Pharmacia Biotech (Arlington Heights, IL, USA). The Cell Titer 96 Aqueous One Solution
Cell Proliferation Assay kit was purchased from Promega (Madison, WI, USA). Mouse anti-pRb antibody was obtained from PharMingen (San Diego, CA, USA). Rabbit polyclonal anti-phospho pRb Ser807/811 was purchased from New England Biolabs (Beverly, MA, USA). Anti-cyclin D1, - $\beta$-actin, -cyclin dependentkinase (cdk) 4 and $-\mathrm{p} 27^{\text {kip1 }}$ were obtained from Santa Cruz LipofectAMINE plus was obtained from Invitrogen (Carlsbad, CA) Biotechnology, Inc. (Santa Cruz, CA, USA). The PicaGene dual sea pansy system was purchased from Toyo Inc. (Tokyo, Japan).

\section{Constructs}

The human ER $\alpha$ expression vector, pIE, was a kind gift from Dr D J Shapiro (University of Illinois, Urbana, IL, USA). The cyclin D1 (D1 pro-1749) promoter plasmid construct, which contains the cyclin D1 regulatory region $(-1749$ to +135$)$ fused to a luciferase reporter gene, was kindly provided by Dr T Shiozawa (Shinshu University School of Medicine, Matsumoto, Japan).

\section{Cell culture}

Primary cultures of human aortic smooth muscle cells (VSMC) (Clonetics, Walkersville, MD, USA) and primary rat aortic smooth muscle cells (A10) (American Type Culture Collection, Rockville, MD, USA) were grown at $37^{\circ} \mathrm{C}$ in Dulbecco's modified Eagle's medium (DMEM) (Life Technologies, Rockville, MD, USA) supplemented with 10\% fetal bovine serum (FBS), 100 units/ml penicillin and $100 \mu \mathrm{g} / \mathrm{ml}$ streptomycin. Cultures were maintained at $37^{\circ} \mathrm{C}$ in a water-saturated atmosphere of $95 \%$ air and $5 \% \mathrm{CO}_{2}$. VSMC cultured for at most ten passages were used for the following studies.

\section{Cell proliferation assay}

Five thousand cells were seeded per well in a 96-well plate, incubated for $24 \mathrm{~h}$ in DMEM with $10 \% \mathrm{FBS}$, and then starved in phenol red-free DMEM with $0 \cdot 4 \%$ charcoal-dextran-treated FBS for $48 \mathrm{~h} . \mathrm{E}_{2} \quad\left(10^{-6}\right.$ to $10^{-8} \mathrm{M}$ ) or vehicle was added $1 \mathrm{~h}$ before VSMC or A10 were challenged with PDGF for $48 \mathrm{~h}$. Cell proliferation was assessed by measuring the absorbance at $490 \mathrm{~nm}$ of the dissolved formazan product formed after addition of 3(4,5-dimethylthiazol-2-yl)-5-(3-carboxylmethoxyphenyl)2-(4-sulfophenyl)-2H-tetrazolium inner salt (MTS) and incubation for $1 \mathrm{~h}$ as described by the manufacturer (Promega). All experiments were carried out in quadruplicate and proliferation was expressed as the ratio of the absorbance of treated cells to that of untreated quiescent cells cultured in $0 \cdot 4 \%$ FBS. For cell number experiments, VSMC were plated at a density of $5 \times 10^{3}$ cells per well in a 24-well plate and allowed to attach overnight. The cells were starved as described above for $48 \mathrm{~h}$, and were then 
treated with fresh preparation of medium containing $\mathrm{E}_{2}$ or raloxifene every $48 \mathrm{~h}$ for 6 days, and counted each time the medium was exchanged. A Neubauer chamber was used to count the cell number and the trypan-blue exclusion test was carried out to determine the cell viability.

\section{Western blotting analysis}

VSMC were starved as described above for $48 \mathrm{~h}$ and then treated with the various agents indicated in the text. They were then washed twice with phosphate-buffered saline (PBS) and lysed in ice-cold lysis buffer $(20 \mathrm{mM}$ Tris, $\mathrm{pH}$ 7·4, $150 \mathrm{mM} \mathrm{NaCl}, 1 \%$ Triton X-100, $1 \mathrm{mM}$ EDTA, $1 \mathrm{mM}$ EGTA, $2.5 \mathrm{mM}$ sodium pyrophosphate, $1 \mathrm{mM}$ $\beta$-glycerol-phosphate, $1 \mathrm{mM}$ sodium orthovanadate, $1 \mu \mathrm{g} /$ $\mathrm{ml}$ leupeptin and $1 \mathrm{mM}$ phenylmethylsulfonyl fluoride). The extracts were centrifuged to remove cellular debris, and the protein content of the supernatants was determined using the Bio-Rad protein assay reagent. Lysate samples containing $40 \mu \mathrm{g}$ protein were boiled and the proteins were separated by electrophoresis on a $10 \%$ glycine-SDS-polyacrylamide gel and electroblotted onto a polyvinylidene difluoride membrane (Hybond-P; Amersham Pharmacia Biotech, Amersham, Bucks, UK). The membrane was incubated with blocking buffer for $1 \mathrm{~h}$ at room temperature, probed with primary antibody with gentle rocking at $4{ }^{\circ} \mathrm{C}$ overnight, and incubated with horseradish peroxidase-conjugated anti-mouse or antirabbit secondary antibody (at 1:2000 dilution) for $1 \mathrm{~h}$ at room temperature. The signal was detected by chemiluminescence with ECL Western blotting detection reagents (Amersham Pharmacia Biotech). All Western blot experiments were repeated at least three times with identical results.

\section{Cell cycle distribution}

Quiescent VSMC were pretreated for $1 \mathrm{~h}$ with $10^{-8} \mathrm{M}$ $\mathrm{E}_{2}$ or vehicle (ethanol), and then treated with $5 \mathrm{ng} / \mathrm{ml}$ PDGF. After $24 \mathrm{~h}$, cells were trypsinized, centrifuged at 1200 r.p.m. for $5 \mathrm{~min}$, washed with PBS, and then treated with RNase A $(20 \mu \mathrm{g} / \mathrm{ml})$. DNA was stained with propidium iodide $(100 \mu \mathrm{g} / \mathrm{ml})$ for $30 \mathrm{~min}$ at $4{ }^{\circ} \mathrm{C}$ in the dark. The DNA content of the cells was analyzed using a Becton Dickinson FACSCalibur flow cytometer (Becton Dickinson, San Jose, CA, USA). DNA histogram analysis was performed using ModFitLT software (Becton Dickinson).

\section{RT-PCR experiments}

Total RNA was extracted from VSMC and A10 cells with Tri-Reagent (Molecular Research Center, Inc., Cincinnati, $\mathrm{OH}$ ) according to the manufacturer's instructions. Total RNA $(5 \mu \mathrm{g})$ was used as a template for
A
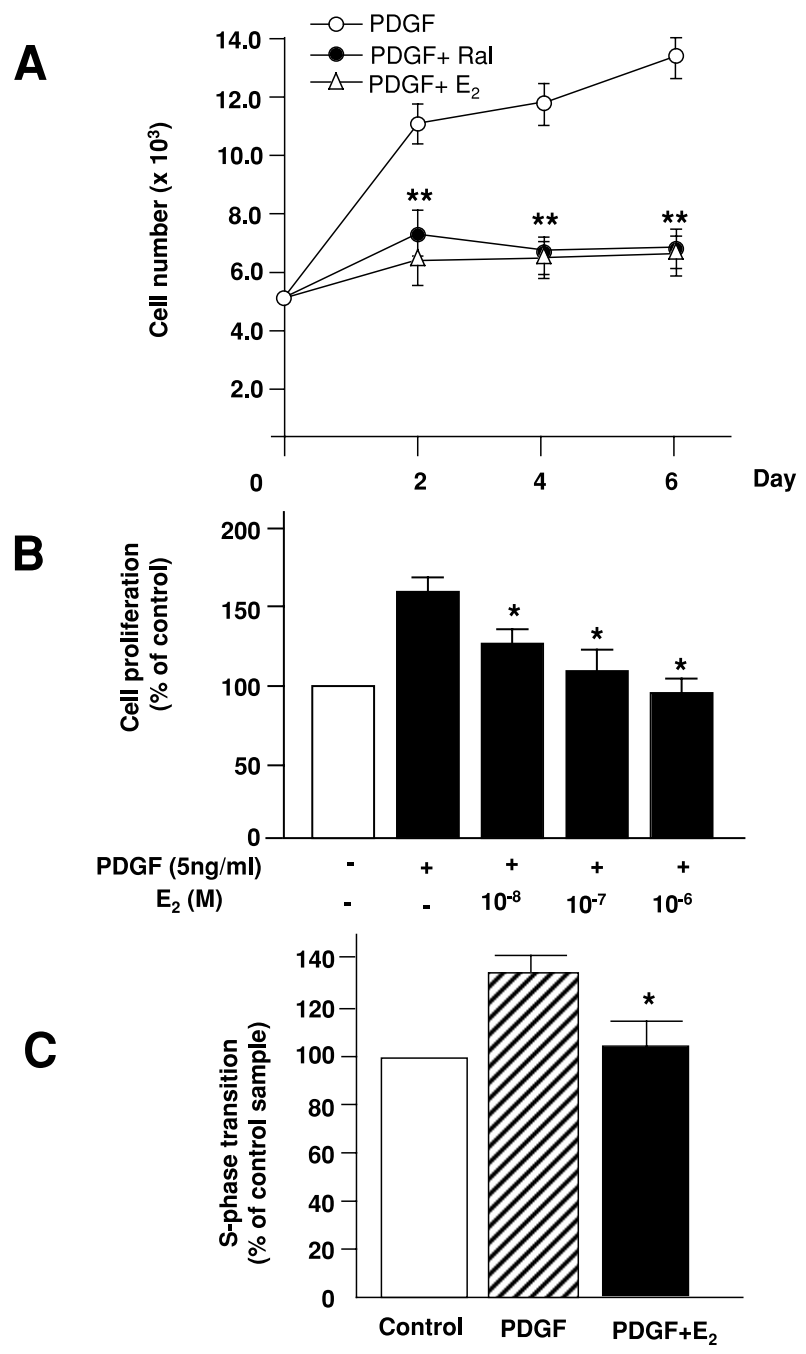

Figure $1 \mathrm{E}_{2}$ and raloxifene (Ral) inhibit PDGF-induced cell proliferation in VSMC. (A) VSMC were starved for $48 \mathrm{~h}$, and then cultured with $5 \mathrm{ng} / \mathrm{ml}$ PDGF alone, or with PDGF in the presence of $E_{2}\left(10^{-8} \mathrm{M}\right)$ or raloxifene $\left(10^{-8} \mathrm{M}\right)$, and then treated with a fresh preparation of medium containing $E_{2}$ or raloxifene every $48 \mathrm{~h}$ for 6 days, and counted each time the medium was exchanged. The viable cell number was determined by the trypan-blue exclusion test. Data are shown as the means \pm S.E.M. from at least three separate experiments. ${ }^{* *} P<0 \cdot 01$ vs VSMC treated with PDGF alone. (B) VSMC were pretreated with various concentrations of $E_{2}$ or vehicle for $1 \mathrm{~h}$, and then treated with $5 \mathrm{ng} / \mathrm{ml}$ PDGF. After $48 \mathrm{~h}$ of incubation with PDGF, cell proliferation was determined by the MTS assay. Cell proliferation is expressed as a percentage of that in the non-stimulated condition (control). Data are shown as the means \pm S.E.M. from at least three separate experiments. ${ }^{*} P<0 \cdot 05$ vs VSMC treated with PDGF alone. (C) Quiescent VSMC were pretreated with $10^{-8} \mathrm{M} \mathrm{E}_{2}$ or vehicle, and then stimulated with $5 \mathrm{ng} / \mathrm{ml}$ PDGF for $24 \mathrm{~h}$. DNA was stained with propidium iodine and cells were analyzed by flow cytometry. The percentage of cells in S phase in the VSMC treated with $\mathrm{PDGF}+\mathrm{E}_{2}$ relative to that in the $\mathrm{VSMC}$ treated with PDGF alone is shown. Data are shown as the means \pm S.E.M. from at least three separate experiments. ${ }^{*} P<0.05$ vs VSMC treated with PDGF alone. 


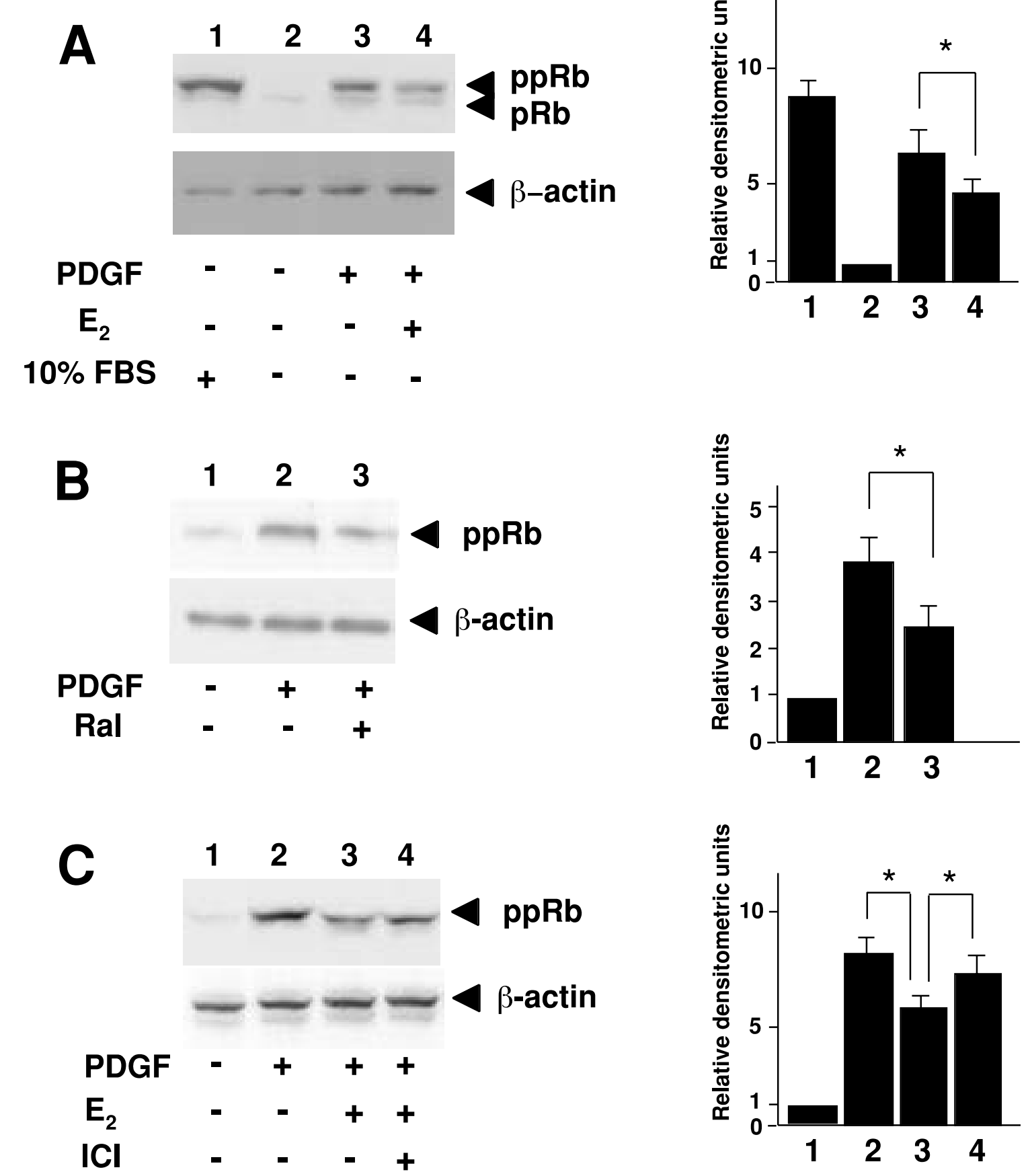

Figure 2 Effects of $E_{2}$ and raloxifene on the phosphorylation of pRb. Quiescent VSMC were pretreated with $10^{-8} M E_{2}(A)$ or $10^{-8} \mathrm{M}$ raloxifene (Ral) (B) for $1 \mathrm{~h}$ before treatment with PDGF $(5 \mathrm{ng} / \mathrm{ml})$ for $24 \mathrm{~h}$. Control VSMC were cultured in growth medium (DMEM with 10\% FBS). To analyze pRb phosphorylation, extracted proteins were resolved by $8 \%$ SDS-PAGE and subjected to Western blotting with anti-pRb antibody (A, upper panel) or antiphospho pRb ser807/811 antibody (B, upper panel). (C) VSMC were pretreated with $1 \mu \mathrm{M} \mathrm{ICI} 182,780(\mathrm{ICI})$ or vehicle for $15 \mathrm{~min}$, and then treated with $10^{-8} \mathrm{M}^{-1}$ $\mathrm{E}_{2}$ or vehicle for $1 \mathrm{~h}$. The cells were then treated with $5 \mathrm{ng} / \mathrm{ml}$ PDGF for $24 \mathrm{~h}$. Extracted proteins were subjected to $8 \%$ SDS-PAGE followed by Western blotting with antiphospho pRb ser807/811 antibody. The positions of the

hypophosphorylated $(\mathrm{pRb})$ and hyperphosphorylated $(\mathrm{ppRb})$ forms of $\mathrm{pRb}$ protein are indicated on the right. $\beta$-Actin analyzed similarly by immunodetection with anti- $\beta$-actin antibody served as a loading control (A-C, lower panel). Relative densitometric units of the ppRb bands are shown in the right panels, with the density of the control bands set arbitrarily at $1 \cdot 0(\mathrm{~A}-\mathrm{C})$. Data are shown as the means \pm S.E.M. from at least three separate experiments. ${ }^{*} P<0 \cdot 05$. 
first-strand cDNA synthesis. cDNA was amplified using an RNA PCR kit obtained from TaKaRa (Tokyo, Japan) according to the manufacturer's instructions. Primers designed based on the published gene sequences were obtained from Amersham Pharmacia Biotech Japan (Tokyo, Japan) and Hitachi Instruments Service Co. Ltd (Tokyo, Japan). The sequences of the PCR primers were as follows: rat ER $\alpha$ : $5^{\prime}$-AATTCTGACAATCGACGC CAG-3' (sense), 5'-GTGCTTCAACATTCTCCCTCC TC-3' (antisense); rat ER $\beta$ : 5'-TTCCCGGCAGCAC CAGTAACC-3' (sense), 5'-TCCCTCTTTGCGTTTG GACTA-3' (antisense); human ER $\alpha$ : $5^{\prime}$-AATTCAGAT AATCGACGCCAG-3' (sense), 5'-GTGTTTCAACAT TCTCCCTCCTC-3' (antisense); human ER $\beta$ : $5^{\prime}$-GTT GCGCCAGCCCTGTTAC-3' (sense), 5'-CTCGTCG GCACTTCTCTGTCTC-3' (antisense). To check the cDNA integrity, glyceraldehyde-3-phosphate dehydrogenase (GAPDH) cDNA was amplified in parallel. All transcripts were analyzed using a GeneAmp PCR System 9700 (Applied Biosystems, Foster City, CA, USA). The amplification profile consisted of 35 cycles of denaturation at $94{ }^{\circ} \mathrm{C}$ for $1 \mathrm{~min}$, primer annealing at $59^{\circ} \mathrm{C}$ for $1 \mathrm{~min}$, and extension at $72^{\circ} \mathrm{C}$ for $1 \mathrm{~min}$. PCR products were electrophoresed on a $1.5 \%$ agarose gel and visualized by ethidium bromide staining under UV illumination.

\section{Cell transfections and reporter gene assays}

Approximately $2 \times 10^{5}$ A10 cells were plated per well of a six-well tissue culture plate $24 \mathrm{~h}$ before transfection. For analysis of the effects of estrogen on reporter gene activity, transfection complexes containing a total of $1.55 \mu \mathrm{g}$ plasmids $(1 \mu \mathrm{g}$ D 1 pro-1749, 0.5 $\mu \mathrm{g}$ pIE and $0.05 \mu \mathrm{g}$ pRLCMV (ToYo Ink, Tokyo, Japan) as an internal control) were added to each well of A10 cells as recommended by the manufacturer (Invitrogen). After $3 \mathrm{~h}$, the transfection cocktail was replaced with growth medium, and the cells were cultured for $24 \mathrm{~h}$. The growth medium was replaced with DMEM containing charcoal-dextran-stripped 0.4\% FBS to induce the A10 cells to become quiescent and the cells were cultured in this medium for $24 \mathrm{~h}$. The quiescent A10 cells were pretreated for $1 \mathrm{~h}$ with $10^{-7} \mathrm{M} \mathrm{E}_{2}$ or vehicle (ethanol), and then treated with $5 \mathrm{ng} / \mathrm{ml}$ PDGF. After $24 \mathrm{~h}$, the cells were harvested and luciferase assays were performed with the PicaGene dual sea pansy system. Firefly-luciferase activity and sea pansy-luciferase activity were measured as relative light units with a luminometer (Lumat LB9507; EG\&G, Berthold, Bad Wildbad, Germany). The firefly-luciferase activity was then normalized relative to the sea pansy-luciferase activity to determine the transfection efficiency.

\section{Statistics}

Statistical analysis was performed by Student's $t$-test, and $P<0.05$ was considered significant. Data are expressed as the means \pm S.E.M.

\section{Results}

\section{Effects of $E_{2}$ and raloxifene on VSMC proliferation}

The effects of raloxifene and $\mathrm{E}_{2}$ on the proliferation of VSMC were evaluated (Fig. 1A). Both $10^{-8} \mathrm{M} \mathrm{E}_{2}$ and $10^{-8} \mathrm{M}$ raloxifene significantly inhibited the growth of VSMC. Pathological proliferation of VSMC plays a major role in the development of atherosclerotic lesions (BraunDullaeus et al. 1998). PDGF released from platelets, macrophages and endothelium is a major trigger of VSMC proliferation. Therefore, we evaluated the effect of $\mathrm{E}_{2}$ or raloxifene on the proliferation of PDGF-stimulated VSMC. When quiescent VSMC were treated with $5 \mathrm{ng} /$ $\mathrm{ml}$ PDGF in $0.4 \%$ FBS for $48 \mathrm{~h}$, the proliferation of the VSMC was stimulated by about $50 \%$ compared with that of the quiescent VSMC. PDGF-stimulated VSMC proliferation was significantly inhibited by $E_{2}$ in a concentration-dependent manner in the range of $10^{-8}$ to $10^{-6} \mathrm{M}$ (Fig. 1B) and also by raloxifene (data not shown). We also determined the effect of $E_{2}$ or raloxifene on PDGF-induced cell cycle progression by flow cytometry. Subconfluent VSMC were synchronized by culturing with $0.4 \% \mathrm{FBS}$ for $48 \mathrm{~h}$, pretreated with $\mathrm{E}_{2}$ or vehicle, and then treated with $5 \mathrm{ng} / \mathrm{ml}$ PDGF. Both $10^{-8} \mathrm{M} \mathrm{E}_{2}$ (Fig. $1 \mathrm{C}$ ) and $10^{-8} \mathrm{M}$ raloxifene (data not shown) reduced the proportion of VSMC that progressed to S phase.

Effects of $E_{2}$ and raloxifene on hyperphosphorylation of $p R b$

Because cell cycle progression is regulated by hyperphosphorylation of $\mathrm{pRb}$, we examined the effects of $\mathrm{E}_{2}$ and raloxifene on $\mathrm{pRb}$ hyperphosphorylation. In quiescent cells, most pRb is hypophosphorylated (Weinberg 1995). Hyperphosphorylation of $\mathrm{pRb}$ is required for S-phase progression in most mammalian cells (Weinberg 1995). Anti-pRb antibody, which recognizes both hyper- and hypophosphorylated $\mathrm{Rb}$ protein, was used to assess the phosphorylation status of $\mathrm{pRb}$. Hyperphosphorylated $\mathrm{pRb}$ $(\mathrm{ppRb})$ was increased in cells cultured with $5 \mathrm{ng} / \mathrm{ml}$ PDGF (Fig. 2A, lane 3) as well as in cells cultured with $10 \%$ FBS (Fig. 2A, lane 1) for $24 \mathrm{~h} . \mathrm{E}_{2}$ clearly attenuated the PDGF-induced increase of ppRb (Fig. 2A, lane 4). To investigate whether raloxifene also decreases the PDGFinduced $\mathrm{ppRb}$, phospho-specific antibody was used to assess the phosphorylation status at Ser807/811 of $\mathrm{pRb}$, which is important for $\mathrm{cdk}$-dependent function. ppRb was increased in cells cultured with $5 \mathrm{ng} / \mathrm{ml}$ PDGF (Fig. 2B, lane 2) and raloxifene clearly decreased the PDGFinduced increase of ppRb (Fig. 2B, lane 3). To investigate whether the inhibitory effect of $E_{2}$ or raloxifene on $\mathrm{pRb}$ phosphorylation is ER-mediated, the effect of ICI 182,780, a potent ER antagonist, was examined. Antiphospho-specific $\mathrm{pRb}$ Western blotting analysis showed that $1 \mu \mathrm{M}$ ICI 182,780 clearly attenuated the inhibitory effects of $\mathrm{E}_{2}$ (Fig. 2C, lane 4) and raloxifene 
(data not shown) on the PDGF-induced hyperphosphorylation of $\mathrm{pRb}$. This result suggested that ER is involved in the antiproliferative effects of $\mathrm{E}_{2}$ and raloxifene in PDGF-stimulated VSMC.

Effects of $E_{2}$ and raloxifene on the protein expression of $G 1$ regulators

The phosphorylation of $\mathrm{pRb}$ is catalyzed, at least in part, by the D-type cyclins and their associated catalytic partners, cdk 4 and cdk6, as well as by cyclin $\mathrm{E}$ and its catalytic partner, cdk2. We therefore examined the effects of $E_{2}$ and raloxifene on the expression of cyclin D1 (Fig. 3). Treatment of cells with $5 \mathrm{ng} / \mathrm{ml}$ PDGF induced the expression of cyclin D1 (Fig. 3A and B, lane 2). $\mathrm{E}_{2}$ at $10^{-8} \mathrm{M}$ (Fig. 3A, lane 4) and raloxifene at $10^{-8} \mathrm{M}$ (Fig. $3 \mathrm{~B}$, lane 4) significantly decreased the PDGF-induced expression of cyclin D1. On the other hand, neither $\mathrm{E}_{2}$ nor raloxifene affected the PDGF-induced expression of cdk4 (data not shown). Induction of cdk inhibitors has been shown to accompany cell cycle arrest in response to various antiproliferative stimuli. Therefore, the effect of $E_{2}$ on the level of $\mathrm{p} 27^{\mathrm{kip} 1}$ was examined. Neither $\mathrm{E}_{2}$ nor raloxifene had any effect on the expression of $\mathrm{p} 27^{\text {kip1 }}$ (data not shown).

Antiproliferative effects of $E_{2}$ and raloxifene are mediated by ERa

Next, we examined which ER is necessary for these effects of $E_{2}$. RT-PCR analysis showed that VSMC expressed both ER $\alpha$ and ER $\beta$ mRNAs (Fig. 4). Although we confirmed that rat uterus expressed $\mathrm{ER} \alpha$ (data not shown), A10 cells, which are derived from the thoracic aorta of embryonic rats and are a commonly used model of VSMC (Weiss et al. 2000), expressed ER $\beta$ but not ER $\alpha$ (Fig. 4). We therefore used A10 cells to examine whether or not ER is involved in the antiproliferative effect of $\mathrm{E}_{2}$. A10 cells that had been induced to enter a quiescent state by incubation in low-serum medium proliferated in response to PDGF stimulation in a dose-dependent manner (Fig. 5A). In contrast to the effect of $\mathrm{E}_{2}$ (Fig. 1B) and raloxifene in VSMC, $\mathrm{E}_{2}$ (Fig 5B) and raloxifene (data not shown) did not significantly inhibit the PDGF-induced proliferation of A10 cells, suggesting that the growth inhibition by estrogen and raloxifene may not be mediated by $\operatorname{ER} \beta$.

We next sought to determine whether $E_{2}$ and raloxifene inhibit the PDGF-induced cyclin D1 promoter activity. A cyclin D1 promoter ( -1749 to $+135 \mathrm{bp})-$ luciferase reporter construct was transiently transfected into A10 cells. As shown in Fig. 6, addition of $5 \mathrm{ng} / \mathrm{ml}$ PDGF for $24 \mathrm{~h}$ enhanced the luciferase activity. To examine whether the inhibition of the PDGF-induced cyclin D1 promoter activity by $\mathrm{E}_{2}$ or raloxifene is mediated by ER $\alpha$, A10 cells were transiently transfected
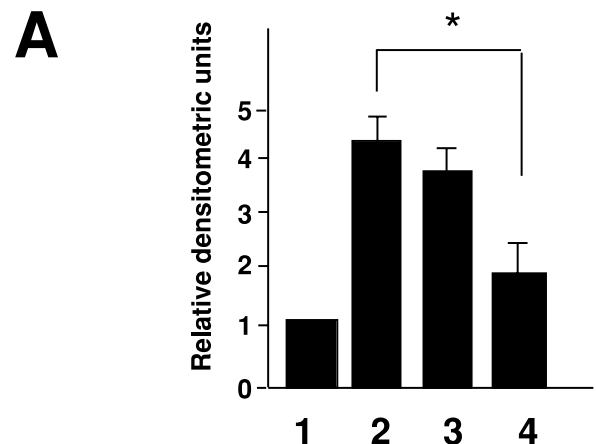

cyclinD1

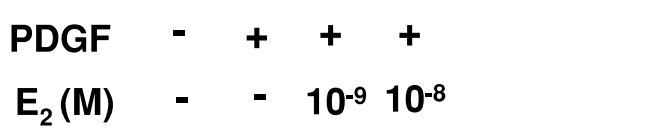

B

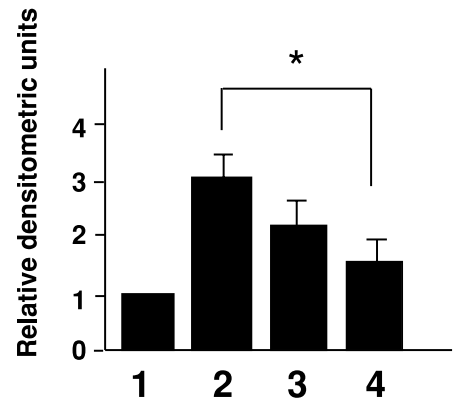

$\beta$-actin
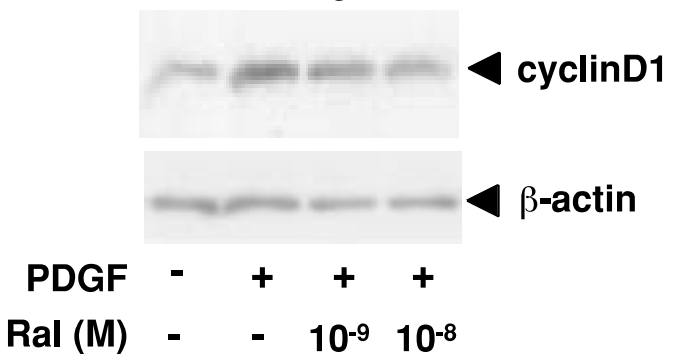

Figure 3 Effects of $E_{2}$ and raloxifene on cyclin D1 expression. Quiescent VSMC were pretreated with $E_{2}(A)$ or raloxifene (Ral) (B) for $1 \mathrm{~h}$ and then treated with $5 \mathrm{ng} / \mathrm{ml}$ PDGF for $6 \mathrm{~h}$. Immunoblotting of cell extracts was performed to detect cyclin D1 ( $A$ and $B$, middle panel). $\beta$-Actin analyzed similarly by immunodetection with anti- $\beta$-actin antibody served as a loading control (A and B, lower panel). Relative densitometric units of the cyclin D1 bands are shown in the upper panels, with the density of the control bands set arbitrarily at 1.0 (A and B). Data are shown as the means \pm S.E.M. from at least three separate experiments. ${ }^{*} P<0 \cdot 05$. 


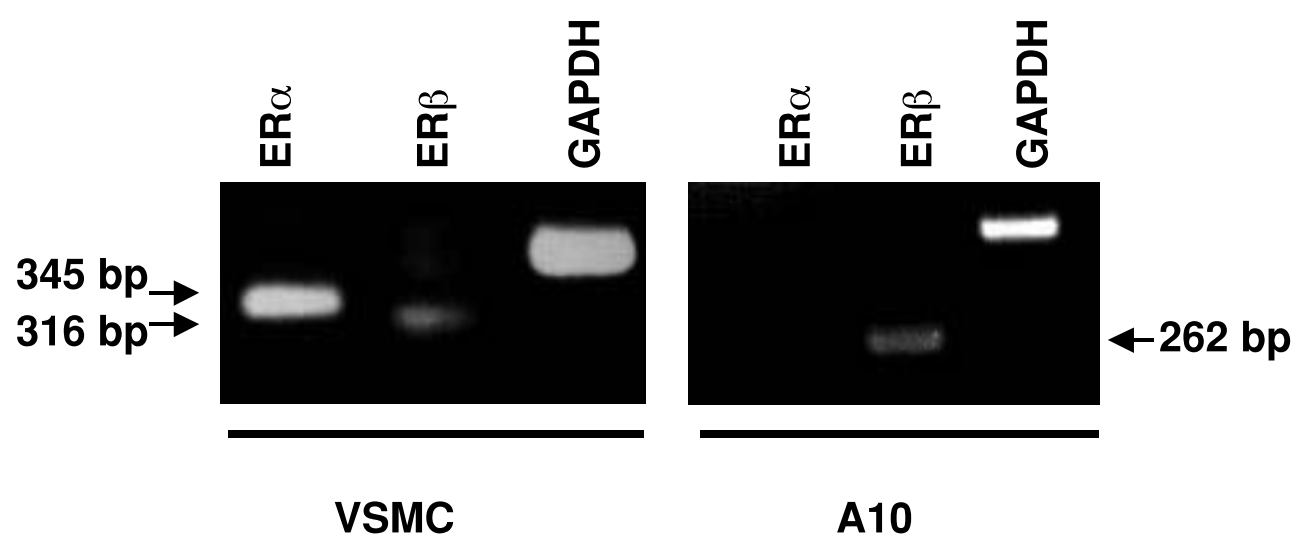

Figure 4 Expression of ER $\alpha$ and $E R \beta$ in VSMC and A10 cells. Total RNA samples were isolated from cultured VSMC and A10 cells. RT-PCR was performed as described in Materials and Methods. The PCR products were resolved by electrophoresis on a $1.5 \%$ agarose gel and stained with ethidium bromide.

with an ER $\alpha$ expression vector in addition to the cyclin D1 reporter construct. Although $\mathrm{E}_{2}$ and raloxifene had no effect on the PDGF-induced cyclin D1 promoter activity in A10 cells, transfection of the ER $\alpha$ expression vector rendered the PDGF-induced cyclin D1 promoter activity sensitive to inhibition by $\mathrm{E}_{2}$ and raloxifene (Fig. 6). These results indicated that $\mathrm{ER} \alpha$ is required for the inhibition of the PDGF-induced cyclin D1 promoter activity by $\mathrm{E}_{2}$ and raloxifene.

\section{Discussion}

We have demonstrated here that $\mathrm{E}_{2}$ and raloxifene inhibit PDGF-induced VSMC proliferation, at least in part by reducing the PDGF-induced $\mathrm{pRb}$ phosphorylation. Protective effects of estrogen against cardiovascular disease in postmenopausal women are well documented (Forrester et al. 1991, Belchetz 1994). Putative mechanisms of these effects involve effects on endothelium-dependent and -independent vasodilation (Williams et al. 1990, 1992, Jiang et al. 1991, Rosano et al. 1993, Gilligan et al. 1994) and improvement in the lipid profile (Belchetz 1994). Estrogen stimulates endothelial nitric oxide synthase (eNOS) activity in vivo (Weiner et al. 1994) and in vitro (Hisamoto et al. 2001b), and inhibits smooth muscle cell proliferation by increasing the endothelium-derived nitric oxide (Garg \& Hassid 1989). Proliferation and migration of VSMC are believed to significantly contribute to intimal thickening in atherosclerosis and venous bypass graft disease (Calcagno et al. 1992). PDGF is known to stimulate both proliferation and migration of VSMC, and the importance of this growth factor in the pathophysiology of intimal hyperplasia has been established. The mechanism of VSMC proliferation and migration is related to the stimulation of mitogen-activated protein kinase (MAP kinase) (Claesson-Welsh 1994, Graves et al. 1996), and the resultant increase of the transcription of many immediate early genes (Chen et al. 1992, Seth et al. 1992), including cyclin D1, which is required for transition from the G0 to the G1 phase in the cell cycle (Abrieu et al. 1996, Lavoie et al. 1996). Although phytoestrogen and estrogen inhibit VSMC proliferation by reducing MAP kinase activity (Dubey et al. 1999, 2000, Hwang et al. 2002), the mechanism of this inhibition by estrogen is not fully understood.

Mitogen-induced VSMC proliferation is inhibited by numerous agents such as sodium salicylate (Marra et al. 2000), doxazocin (Kintscher et al. 2000), retinoids (Wakino et al. 2001), 3-hydroxyl-3-methylglutraryl coenzyme A (HMG-CoA) reductase inhibitor (Yang et al. 2000), parathyroid hormone-related protein (Stuart et al. 2000) and dexamethasone (Reil et al. 2000). Studies of the inhibitory effects of these agents have mainly focused on the inhibition of $\mathrm{pRb}$ phosphorylation. $\mathrm{pRb}$ is hypophosphorylated in quiescent cells and binds to transcriptional factor E2F. E2F activates the transcription of genes required for S-phase DNA synthesis, including the genes for thymidine kinase dihydrofolate reductase, cell division cycle 2 and cyclin A (Nevins 1992, La Thangue 1996). Thus, $\mathrm{pRb}$ phosphorylation is among the most crucial steps regulating progression of the cell cycle. In this study, $\mathrm{E}_{2}$ and raloxifene significantly inhibited the PDGFstimulated $\mathrm{pRb}$ phosphorylation (Fig. 2). The inhibitory effect of $\mathrm{E}_{2}$ on $\mathrm{pRb}$ phosphorylation was significant and similar to the effects reported for various other agents that inhibit the proliferation of VSMC (Kintscher et al. 2000, Marra et al. 2000, Yang et al. 2000, Wakino et al. 2001). In addition, some reports have shown that $\mathrm{E}_{2}$ inhibited $\left[{ }^{3} \mathrm{H}\right]$ thymidine incorporation into PDGF-stimulated VSMC and decreased $\left[{ }^{3} \mathrm{H}\right]$ thymidine uptake rates to approximately $60-70 \%$ of the control rates (Suzuki et al. 1996, Dubey et al. 2000). Collectively, the findings of the present study together with the published data indicate 


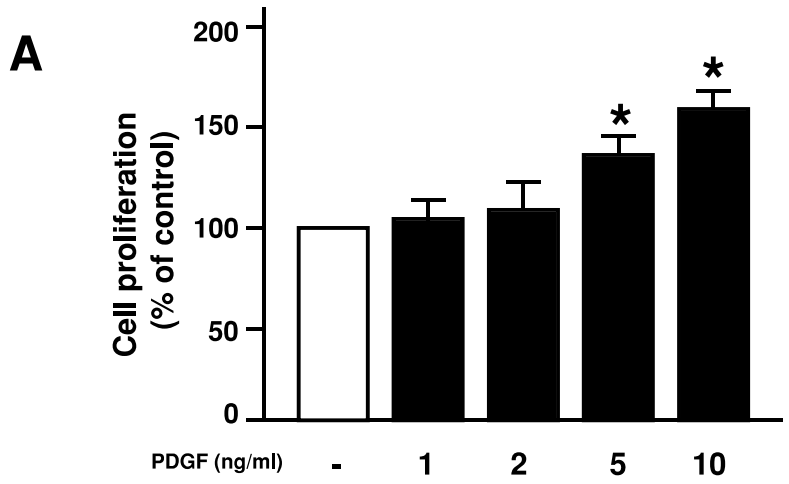

B

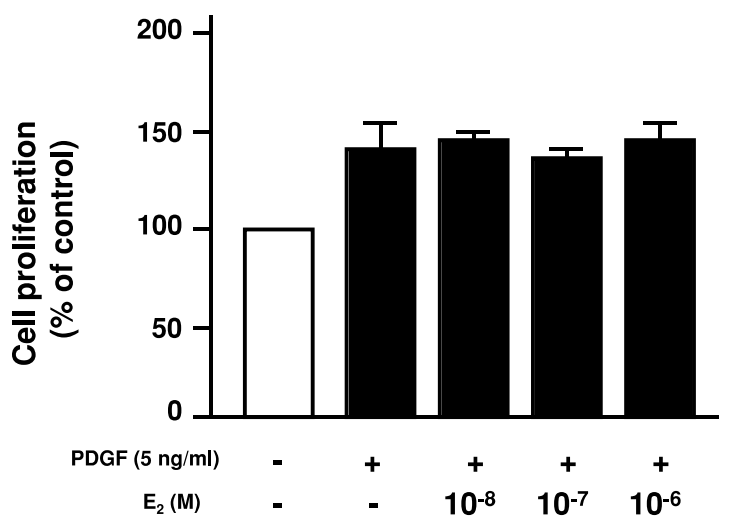

Figure $5 \mathrm{E}_{2}$ does not inhibit PDGF-stimulated proliferation of A10 cells. A10 cells were stimulated with various concentrations of PDGF (A) or pretreated with various concentrations of $E_{2}$ for $1 \mathrm{~h}$ followed by PDGF $(5 \mathrm{ng} / \mathrm{ml})$ stimulation (B). Cell proliferation is expressed as a percentage of that of A10 cells without PDGF stimulation. Data are shown as the means \pm S.E.M. from at least three separate experiments. ${ }^{*} P<0.05$ vs A10 cells without PDGF stimulation.

that the inhibitory effect of $\mathrm{E}_{2}$ on S-phase transition is partial rather than complete in VSMC.

We investigated whether or not $\mathrm{E}_{2}$-induced $\mathrm{G} 1$ arrest was dependent upon ER. Pretreatment with ICI 182,780, a specific ER antagonist, restored the status of $\mathrm{pRb}$ phosphorylation from the hypophosphorylated to the hyperphosphorylated state (Fig. 2C). This result indicated that the inhibitory effect of $\mathrm{E}_{2}$ on $\mathrm{pRb}$ phosphorylation was mediated by ER. The expression of two ER subtypes, $\mathrm{ER} \alpha$ and $\mathrm{ER} \beta$, is observed in VSMC; however, which subtype is responsible for the atheroprotective effect of $E_{2}$ has not hitherto been determined. A10 cells, a primary rat embryonic thoracic aorta cell line, have commonly been used as a model of VSMC. We found that A10 cells expressed ER $\beta$, but not ER $\alpha$ (Fig. 4). Although the proliferation of A10 cells was increased by PDGF similarly to that of VSMC, $\mathrm{E}_{2}$ could not inhibit the PDGF-induced proliferation of A10 cells (Fig. 5). Moreover, although $\mathrm{E}_{2}$ did not inhibit the PDGF-induced cyclin D1 promoter

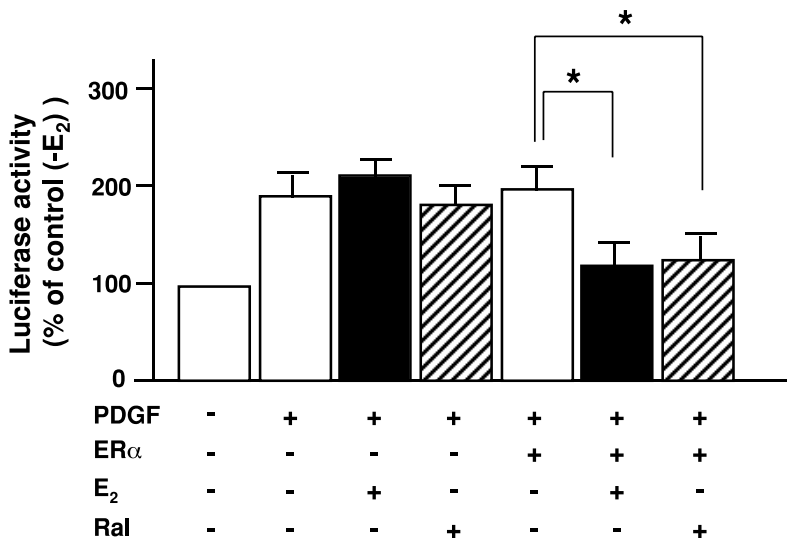

Figure 6 Cyclin D1 promoter activity is suppressed by $E_{2}$ or raloxifene (Ral) via ER $\alpha$. A10 cells were transfected with a plasmid containing a cyclin D1 promoter-luciferase gene fusion construct (D1 pro-1749) together with an ER $\alpha$ expression vector (pIE) (+) or vector alone $(-)$ and pRL-CMV internal control plasmid, as described in Materials and Methods. Transfected cells were pretreated with $10^{-8} \mathrm{ME}_{2}$ or $10^{-8} \mathrm{M}$ raloxifene for $1 \mathrm{~h}$ and then stimulated with $5 \mathrm{ng} / \mathrm{ml}$ PDGF for 24 h. Firefly-luciferase activity, normalized by sea pansy-luciferase activity, was expressed as a percentage of the activity obtained in the absence of $E_{2}$ or raloxifene in cells transfected with pIE or vector alone. Data are shown as the means \pm S.E.M. from at least three separate experiments. ${ }^{*} P<0 \cdot 05$.

activity in A10 cells, $\mathrm{E}_{2}$ significantly inhibited the PDGFinduced cyclin D1 promoter activity in A10 cells transfected with ER $\alpha$ (Fig. 6). These results suggested that the inhibitory effect of $\mathrm{E}_{2}$ on the PDGF-induced proliferation of VSMC was mediated by ER $\alpha$. However, the fact that $\mathrm{ER} \beta$ is the predominantly expressed form of ER in VSMC suggests that the protective effects of estrogens in the cardiovascular system may be due to the genomic effects of ER $\beta$ in vascular tissue (Hodges et al. 2000). In addition, it was reported that estrogen inhibited VSMC proliferation in response to vascular injury in knockout mice lacking ER $\alpha$ (Iafrati et al. 1997). However, ER $\alpha$ may be involved in the protective effects because this knockout mouse expressed a variant ER $\alpha$ (Kos et al. 2002). Our data are in agreement with the recent finding that $\operatorname{ER} \alpha$ mediates the protective effects of estrogen against vascular injury (Pare et al. 2002).

Estrogen is now believed to exert rapid membrane effects independently of the classical gene activation pathway of steroid action. Recently we (Hisamoto et al. 2001a,b) and other groups (Haynes et al. 2000, Simoncini et al. 2000) have shown that estrogen induces the activation of eNOS in a non-genomic manner in vascular endothelial cells. In VSMC, inhibition of $\mathrm{Ca}^{2+}$ influx via L-type $\mathrm{Ca}^{2+}$ channels by estrogen is one of estrogen's acute, non-genomic vasodilator actions (Ruehlmann et al. 1998), estrogen inhibits lysophosphatidylcholine-induced proliferation via a non-genomic antioxidant mechanism 
(Yoon et al. 2001), and estrogen inhibits angiotensin II-induced proliferation via the activation and induction of phosphatases through non-genomic as well as genomic signaling (Takeda-Matsubara et al. 2002). Moreover, it was reported that in MCF-7 cells estrogen rapidly stimulates a p85-regulated phosphatylinositol kinase and Akt, and increases the expression and promoter activity of cyclin D1 as well as the entry of cells into $\mathrm{S}$ phase (Castoria et al. 2001). We recently found that $E_{2}-$ and raloxifene-induced inhibition of VSMC growth is in part due to induction of apoptosis through the p38 cascade with a non-genomic mechanism (authors' unpublished data). However, it remains unclear whether the inhibitory effects of estrogen on the PDGF-induced cyclin D1 promoter activity, $\mathrm{pRb}$ phosphorylation and S-phase entry observed in the present study are mediated in a genomic or non-genomic manner. These inhibitory effects of $E_{2}$ and raloxifene were not as rapid as the effects of estrogen and raloxifene on eNOS activation (Hisamoto et al. 2001a,b). Moreover, actinomycin D, an inhibitor of gene transcription, was tested to rule out the influence of non-genomic events, and it inhibited the effects of $\mathrm{E}_{2}$ and raloxifene observed in the present study (data not shown). We therefore consider it likely that the effects of $\mathrm{E}_{2}$ and raloxifene which we observed here mainly depend on the genomic effects of estrogen mediated by ER $\alpha$.

Although estrogen enhances the proliferation of breast or uterine cells and has anti-apoptotic effects in vascular endothelial cells (Razandi et al. 2000), estrogen inhibits the proliferation of VSMC. In addition, it has been reported that estrogen induces apoptosis in an erythroid cell line (Blobel \& Orkin 1996) and induces apoptosis and G1 cell cycle arrest of human multiple myeloma cells (Treon et al. 1998, Wang et al. 2001). Thus, $\mathrm{E}_{2}$ modulates diverse cell functions in a cell- and tissue-specific manner. Although the mechanism of this heterogeneity of estrogen's actions remains unknown, it is possible that it involves 'cross-talk' between membrane-mediated events and nuclear receptor activation.

VSMC proliferation is regulated by direct cell cyclespecific effects as well as indirect effects via the regulation of VSMC mitogen production by endothelial cells (Kourembanas et al. 1998). Thus, it is possible that the inhibitory effects of $E_{2}$ and raloxifene on VSMC proliferation are mediated by direct cell cycle-specific effects. It was reported recently that VSMC express telomerase activity when stimulated to proliferate (Minamino \& Kourembanas 2001). We are therefore now investigating the effects of $E_{2}$ and raloxifene on telomerase activity.

\section{References}

Abrieu A, Lorca T, Labbe JC, Morin N, Keyse S \& Doree M 1996 MAP kinase does not inactivate, but rather prevents the cyclin degradation pathway from being turned on in Xenopus egg extracts. Journal of Cell Science 109 239-246.
Belchetz PE 1994 Hormonal treatment of postmenopausal women. New England Journal of Medicine 330 1062-1071.

Blobel GA \& Orkin SH 1996 Estrogen-induced apoptosis by inhibition of the erythroid transcription factor GATA-1. Molecular and Cellular Biology 16 1687-1694.

Braun-Dullaeus RC, Mann MJ \& Dzau VJ 1998 Cell cycle progression: new therapeutic target for vascular proliferative disease. Circulation 98 82-89.

Calcagno D, Bei M, Ross SA, Klein A \& Foegh ML 1992 Effects of estrogen on vein grafts. Journal of Cardiovascular Surgery 33 579-584.

Castoria G, Migliaccio A, Bilancio A, Di Domenico M, de Falco A, Lombardi M, Fiorentino R, Varricchio L, Barone MV \& Auricchio F 2001 PI3-kinase in concert with Src promotes the S-phase entry of oestradiol-stimulated MCF-7 cells. EMBO Journal 20 6050-6059.

Claesson-Welsh L 1994 Platelet-derived growth factor receptor signals. Journal of Biological Chemistry 269 32023-32026.

Chen RH, Sarnecki C \& Blenis J 1992 Nuclear localization and regulation of erk- and rsk-encoded protein kinases. Molecular and Cellular Biology 12 915-927.

Cummings SR, Eckert S, Krueger KA, Grady D, Powles TJ, Cauley JA, Norton L, Nickelsen T, Bjarnason NH, Morrow M, Lippman ME, Black D, Glusman JE, Costa A \& Jordan VC 1999 The effect of raloxifene on risk of breast cancer in postmenopausal women: results from the MORE randomized trial. Multiple Outcomes of Raloxifene Evaluation. Journal of the American Medical Association 282 2189-2197.

Dai-Do D, Espinosa E, Liu G, Rabelink TJ, Julmy F, Yang Z, Mahler F \& Lusscher TF 1996 17 $\beta$-Estradiol inhibits proliferation and migration of human vascular smooth muscle cells: similar effects in cells from postmenopausal females and in males. Cardiovascular Research 32 980-985.

Dubey RK, Gillespie DG, Imthurn B, Rosselli M, Jackson EK \& Keller PJ 1999 Phytoestrogens inhibit growth and MAP kinase activity in human aortic smooth muscle cells. Hypertension $\mathbf{3 3}$ 177-182.

Dubey RK, Jackson EK, Gillespie DG, Zacharia LC, Imthurn B \& Keller PJ 2000 Clinically used estrogens differentially inhibit human aortic smooth muscle cell growth and mitogen-activated protein kinase activity. Arteriosclerosis, Thrombosis, and Vascular Biology 20 964-972.

Forrester JS, Fishbein M, Helfant R \& Fagin J 1991 A paradigm for restenosis based on cell biology: clues for the development of new preventive therapies. Journal of the American College of Cardiology 17 758-769.

Garg UC \& Hassid A 1989 Nitric oxide-generating vasodilators and 8-bromo-cyclic guanosine monophosphate inhibit mitogenesis and proliferation of cultured rat vascular smooth muscle cells. Journal of Clinical Investigation 83 1774-1777.

Gilligan DM, Badar DM, Panza JA, Quyyumi AA \& Cannon RO 3rd 1994 Acute vascular effects of estrogen in postmenopausal women. Circulation 90 786-791.

Graves LM, Bornfeldt KE, Sidhu JS, Argast GM, Raines EW, Ross R, Leslie CC \& Krebs EG 1996 Platelet-derived growth factor stimulates protein kinase A through a mitogen-activated protein kinase-dependent pathway in human arterial smooth muscle cells. Journal of Biological Chemistry 271 505-511.

Hanke H 1996 Proliferative response of smooth muscle cells after experimental balloon angioplasty. Circulation 93202.

Haynes MP, Sinha D, Russell KS, Collinge M, Fulton D, Morales-Ruiz M, Sessa WC \& Bender JR 2000 Membrane estrogen receptor engagement activates endothelial nitric oxide synthase via the PI3-kinase-Akt pathway in human endothelial cells. Circulation Research 87 677-682.

Hisamoto K, Ohmichi M, Kanda K, Adachi K, Nishio Y, Hayakawa J, Mabuchi S, Takahashi K, Tasaka K, Miyamoto Y, Taniguchi N \& Murata Y 2001a Induction of endothelial nitric-oxide synthase phosphorylation by the raloxifene analog LY117018 is differentially 
mediated by Akt and extracellular signal-regulated protein kinase in vascular endothelial cells. Journal of Biological Chemistry 276 47642-47649.

Hisamoto K, Ohmichi M, Kurachi H, Hayakawa J, Kanda Y, Nishio Y, Adachi K, Tasaka K, Miyoshi E, Fujiwara N, Taniguchi N \& Murata Y $2001 b$ Estrogen induces the Akt-dependent activation of endothelial nitric-oxide synthase in vascular endothelial cells. Journal of Biological Chemistry 276 3459-3467.

Hodges YK, Tung L, Yan XD, Graham JD, Horwitz KB \& Horwitz LD 2000 Estrogen receptors alpha and beta: prevalence of estrogen receptor beta mRNA in human vascular smooth muscle and transcriptional effects. Circulation 101 1792-1798.

Hwang KC, Lee KH \& Jang Y 2002 Inhibition of MEK1,2/ERK mitogenic pathway by estrogen with antiproliferative properties in rat aortic smooth muscle cells. Journal of Steroid Biochemistry and Molecular Biology 80 85-90.

Iafrati MD, Karas RH, Aronovitz M, Kim S, Sullivan TR Jr, Lubahn DB, O’Donnell TF Jr, Korach KS \& Mendelsohn ME 1997 Estrogen inhibits the vascular injury response in estrogen receptor alpha-deficient mice. Nature Medicine 3 545-548.

Jiang CW, Sarrel PM, Lindsay DC, Poole-Wilson PA \& Collins P 1991 Endothelium-independent relaxation of rabbit coronary artery by 17 beta-oestradiol in vitro. British Journal of Pharmacology 104 1033-1037.

Kintscher U, Wakino S, Kim S, Jackson SM, Fleck E, Hsueh WA \& Law RE 2000 Doxazosin inhibits retinoblastoma protein phosphorylation and $\mathrm{G}_{1} \rightarrow \mathrm{S}$ transition in human coronary smooth muscle cells. Arteriosclerosis, Thrombosis, and Vascular Biology 20 1216-1224.

Kolodgie FD, Jacob A, Wilson PS, Carlson GC, Farb A, Verma A \& Virmani R 1996 Estradiol attenuates directed migration of vascular smooth muscle cells in vitro. American Journal of Pathology $\mathbf{4 8}$ 969-976.

Kos M, Denger S, Reid G, Korach KS \& Gannon F 2002 Down but not out? A novel protein isoform of the estrogen receptor alpha is expressed in the estrogen receptor alpha knockout mouse. Journal of Molecular Endocrinology 3 281-286.

Kourembanas S, Morita T, Christou H, Liu Y, Koike H, Brodsky D, Arthur V \& Mitsial SA 1998 Hypoxic responses of vascular cells. Chest 114 25S-28S.

La Thangue NB 1996 E2F and the molecular mechanisms of early cell-cycle control. Biochemical Society Transactions 24 54-59.

Lavoie JN, L'Allemain G, Brunet A, Muller R \& Pouyssegur J 1996 Cyclin D1 expression is regulated positively by the p42/p44 MAPK and negatively by the p38/HOGMAPK pathway. Journal of Biological Chemistry 271 20608-20616.

Marra DE, Simoncini T \& Liao JK 2000 Inhibition of vascular smooth muscle cell proliferation by sodium salicylate mediated by upregulation of $\mathrm{p} 21^{\text {waf1 }}$ and $\mathrm{p} 27^{\mathrm{kip} 1}$. Circulation 102 2124-2130.

Mendelsohn ME \& Karas RH 1999 The protective effects of estrogen on the cardiovascular system. New England Journal of Medicine 340 1801-1811.

Minamino T \& Kourembanas S 2001 Mechanisms of telomerase induction during vascular smooth muscle cell proliferation. Circulation Research 89 237-243.

Moncada S \& Higgs A 1993 The L-arginine-nitric oxide pathway. New England Journal of Medicine 329 2002-2012.

Nevins JR 1992 E2F: a link between the Rb tumor suppressor protein and viral oncoproteins. Science 258 424-429.

Pare G, Krust A, Karas RH, Dupont S, Aronovitz M, Chambon P \& Mendelsohn ME 2002 Estrogen receptor-alpha mediates the protective effects of estrogen against vascular injury. Circulation Research 90 1087-1092.

Razandi M, Pedram A \& Levin ER 2000 Estrogen signals to the preservation of endothelial cell form and function. Journal of Biological Chemistry 275 38540-38546.
Reil TD, Kashyap VS, Sarkar R, Freishlag J \& Gelabert HA 2000 Dexamethasone inhibits the phosphorylation of retinoblastoma protein in the suppression of human vascular smooth muscle cell proliferation. Journal of Surgical Research 92 108-113.

Rosano GM, Sarrel PM, Poole-Wilson PA \& Collins P 1993 Beneficial effect of oestrogen on exercise-induced myocardial ischaemia in women with coronary artery disease. Lancet $\mathbf{3 4 2}$ 133-136.

Ross R 1986 The pathogenesis of atherosclerosis - an update. New England Journal of Medicine 314 488-500.

Ross R 1995 Cell biology of atherosclerosis. Annual Review of Physiology 57 791-804.

Ruehlmann DO, Steinert JR, Valverde MA, Jacob R \& Mann GE 1998 Environmental estrogenic pollutants induce acute vascular relaxation by inhibiting L-type $\mathrm{Ca}^{2+}$ channels in smooth muscle cells. FASEB Journal 12 613-619.

Schwartz SM, deBlois D \& O'Brien ER 1995 The intima: soil for atherosclerosis and restenosis. Circulation Research 77 445-465.

Seth A, Gonzalez FA, Gupta S, Raden DL \& Davis RJ 1992 Signal transduction within the nucleus by mitogen-activated protein kinase. Journal of Biological Chemistry 267 24796-24804.

Simoncini T, Hafezi-Moghadam A, Brazil DP, Ley K, Chin WW \& Liao JK 2000 Interaction of oestrogen receptor with the regulatory subunit of phosphatidylinositol-3-OH kinase. Nature 407 538-541.

Somjen D, Kohen F, Jaffe A, Amir-Zaltsman A, Knoll E \& Stern N 1998 Effects of gonadal steroids and their antagonists on DNA synthesis in human vascular cells. Hypertension 32 39-45.

Stampfer MJ, Colditz GA, Willett WC, Manson JE, Rosner B, Speizer FE \& Hennekens CH 1991 Postmenopausal estrogen therapy and cardiovascular disease. Ten-year follow-up from the nurses' health study. New England Journal of Medicine 325 756-762.

Stuart WD, Maeda S, Khera P, Fagin JA \& Clemens TL 2000 Parathyroid hormone-related protein induces G1 phase growth arrest of vascular smooth muscle cells. American Journal of Physiology: Endocrinology and Metabolism 279 E60-E67.

Sullivan TR Jr, Karas RH, Aronovitz M, Faller GT, Ziar JP, Smith JJ, O'Donnell TF Jr \& Mendelsohn ME 1995 Estrogen inhibits the response-to-injury in a mouse carotid artery model. Journal of Clinical Investigation 96 2482-2488.

Suzuki A, Mizuno K, Ino Y, Okada M, Kikkawa F, Mizutani S \& Tomoda Y 1996 Effect of $17 \beta$-estradiol and progesterone on growth-factor-induced proliferation and migration in human female aortic smooth muscle cells in vitro. Cardiovascular Research 32 $516-523$.

Takeda-Matsubara Y, Nakagami H, Iwai M, Cui TX, Shiuchi T, Akishita M, Nahmias C, Ito M \& Horiuchi M 2002 Estrogen activates phosphatases and antagonizes growth-promoting effect of angiotensin II. Hypertension 39 41-45.

Treon SP, Teoh G, Urashima M, Ogata A, Chauhan D, Webb IJ \& Anderson KC 1998 Anti-estrogens induce apoptosis of multiple myeloma cells. Blood 92 1749-1757.

Wakino S, Kintscher U, Kim S, Jackson S, Yin F, Nagpal S, Chandraratna RA, Hsueh WA \& Law RE 2001 Retinoids inhibit proliferation of human coronary smooth muscle cells by modulating cell cycle regulators. Arteriosclerosis, Thrombosis, and Vascular Biology 21 746-751.

Wang LH, Yang XY, Mihalic K, Xiao W, Li D \& Farrar WL 2001 Activation of estrogen receptor blocks interleukin-6-inducible cell growth of human multiple myeloma involving molecular cross-talk between estrogen receptor and STAT3 mediated by co-regulator PIAS3. Journal of Biological Chemistry 276 31839-31844.

Weinberg RA 1995 The retinoblastoma protein and cell cycle control. Cell 81 323-330.

Weiner CP, Lizasoain I, Baylis SA, Knowles RG, Charles IG \& Moncada S 1994 Induction of calcium-dependent nitric oxide synthases by sex hormones. PNAS 91 5212-5216. 


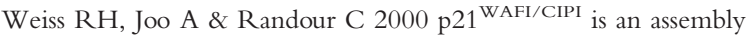
factor required for platelet-derived growth factor-induced vascular smooth muscle cell proliferation. Journal of Biological Chemistry 275 10285-10290.

Williams JK, Adams MR \& Klopfenstein HS 1990 Estrogen modulates responses of atherosclerotic coronary arteries. Circulation 81 1680-1687.

Williams JK, Adams MR, Herrington DM \& Clarkson TB 1992

Short-term administration of estrogen and vascular responses of atherosclerotic coronary arteries. Journal of the American College of Cardiology 20 452-457.

Writing Group for the Women's Health Initiative Investigators 2002 Risks and benefits of estrogen plus progestin in healthy postmenopausal women: principal results from the Women's Health Initiative randomized controlled trial. Journal of the American Medical Association 288 321-333.
Yang Z, Kozaki T, von der Loo B, Viswambharan H, Lachat M \& Turina MI 2000 HMG-CoA reductase inhibition improves endothelial cell function and inhibits smooth muscle cell proliferation in human saphenous veins. Journal of the American College of Cardiology 36 1691-1697.

Yoon BK, Oh WJ, Kessel B, Roh CR, Choi D, Lee JH \& Kim DK 200117 Beta-estradiol inhibits proliferation of cultured vascular smooth muscle cells induced by lysophosphatidylcholine via a nongenomic antioxidant mechanism. Menopause 8 58-64.

Received 3 March 2003

Accepted 15 May 2003 